\title{
Przyszłość polityki ekspedycyjnej Unii Europejskiej w ramach Wspólnej Polityki Bezpieczeństwa i Obrony
}

\section{Wprowadzenie}

Spoglądając na rozwój wydarzeń w Europie i na świecie oraz ich negatywnych skutków transferowanych do Unii Europejskiej (UE) zastanawiamy się jaką rolę odgrywają zewnętrzne, sektorowe polityki UE, aby zapobiegać, zmniejszać, czy niwelować zagrożenia związane chociażby z rozwojem terroryzmu czy innymi konfliktami, w tym hybrydowymi, toczącymi się tuż przy granicach UE? Import zjawisk stanowiących zagrożenie dla bezpieczeństwa wewnętrznego Unii Europejskiej w dość bolesny sposób odbija się na państwach członkowskich, powodując chaos na szczeblach decyzyjnych, co w konsekwencji osłabia całą UE. To z kolei wpływa na postrzeganie Unii Europejskiej jako słabej, nieradzącej sobie z problemami. W kwietniu tego roku Wysoka Przedstawiciel Unii ds. Zagranicznych i Polityki Bezpieczeństwa Federica Mogherini powiedziała: „W ostatnich latach zaszły radykalne zmiany w środowisku bezpieczeństwa. Mieliśmy do czynienia ze wzrostem zagrożeń hybrydowych na granicach UE. UE stanowczo wezwano do dostosowania i zwiększenia jej potencjału jako gwaranta bezpieczeństwa. Związek między bezpieczeństwem wewnętrznym i zewnętrznym musi być nadal wzmacniany. Za pomocą tych nowych wniosków chcemy zwiększyć naszą zdolność do zwalczania zagrożeń o charakterze hybrydowym. [...]”. Wnioski z ostatnich lat są takie, że bezsprzecznie Unia Europejska jest w coraz większym stopniu narażona na zagrożenia hybrydowe, obejmujące wrogie działania zmierzające do destabilizacji określonego regionu lub państwa (Hybrydowe zagrożenia, 2016). Dlatego już wcześniej należało podjąć działania (zamiast przyjmować wnioski), które w sposób synergiczny wykorzystywałyby dostępne narzędzia, zarówno w wymiarze wewnętrznym, jak i zewnętrznym. Celem niniejszego artykułu jest analiza roli i przyszłości polityki ekspedycyjnej w ramach WPBiO i jej oddziaływania na bezpieczeństwo wewnętrzne i zewnętrzne Unii Europejskiej.

Niezbędnym narzędziem badawczym w przypadku analizowanego problemu okazała się metoda instytucjonalno-prawna. Akty normatywne, szczególnie sui generis, stanowią istotne instrumentarium w polityce ekspedycyjnej, rozumianej w niniejszym artykule jako wszelkie działania zewnętrzne (cywilne i wojskowe) prowadzone przez $\mathrm{UE}$ w ramach WPBiO.

Pewne jest to, że Unii nie brakuje instrumentarium do przeciwdziałania wspomnianym zagrożeniom. Zarówno w wymiarze wewnętrznym posiada ona specjalnie do tego stworzone instrumenty, jak i w wymiarze zewnętrznym. Zatem należy w tym miejscu zadać sobie pytanie, czy podejmowane działania ekspedycyjne w ramach Wspólnej Polityki Bezpieczeństwa i Obrony (WPBiO), która jest bez wątpienia sektorową po- 
lityką UE ukierunkowaną na działania zewnętrzne, są w stanie wpływać na poprawę bezpieczeństwa zewnętrznego, ale i wewnętrznego UE? I jaka przyszłość czeka tą sektorową politykę UE?

\section{WPZiB i WPBiO a dzialania ekspedycyjne}

Aby rozpocząć analizę tego zagadnienia konieczne jest wyjście od roli Wspólnej Polityki Zagranicznej i Bezpieczeństwa (WPZiB) Unii Europejskiej, w ramach której narodziła się początkowo Europejska Polityka Bezpieczeństwa i Obrony (EPBiO), następnie przemianowana na WPBiO. W art. 24, ust. 1 TUE zostało zapisane, że: „Kompetencje Unii w zakresie wspólnej polityki zagranicznej i bezpieczeństwa obejmują wszelkie dziedziny polityki zagranicznej i ogół kwestii dotyczących bezpieczeństwa Unii, w tym stopniowe określanie wspólnej polityki obronnej, która może prowadzić do wspólnej obrony". Dodatkowo w art. 23 podkreśla się, że działania Unii Europejskiej na arenie międzynarodowej (w kontekście WPZiB) opierają się na zasadach, które UE ustanawia i które pozwolą jej na osiagnnięcie założonych celów, również w obszarze bezpieczeństwa. Dlatego też konstytutywnym narzędziem polityki zagranicznej wydają się być działania ekspedycyjne UE, mające na celu realizację założeń jej polityki zagranicznej.

Istotą polityki zagranicznej Unii Europejskiej był przede wszystkim zamiar oddziaływania (impact) przez nią na otoczenie zewnętrzne za pomocą licznych instrumentów politycznych, prawnych i gospodarczych, a także wojskowych i cywilnych - stąd też konsekwentne budowanie wspólnego podejścia (common approach, czy też joined-up approach) do kwestii bezpieczeństwa i obrony - oraz poprzez wykorzystanie w tym celu własnej atrakcyjności cywilizacyjnej-kreowanie soft power.

Celem podstawowym Unii Europejskiej w zakresie WPZiB jest zadbanie o stabilizację sytuacji w obszarach uznawanych przez wiodąca grupę państw UE za kluczowe dla ich interesów (Żurawski vel Grajewski, 2012, s. 3; Zwanenburg, 2005; Youngs, 2004). Dzięki powstaniu WZPiB Unia Europejska nie tylko zatem mogła ochronić swoje wartości, ale także była w stanie eksportować je do państw trzecich, dbając przy tym o swoje interesy, niezależność, integralność i bezpieczeństwo.

Wspólna Polityka Zagraniczna i Bezpieczeństwa pozwala na umacnianie i wspieranie demokracji, państwa prawnego, praw człowieka i zasad prawa międzynarodowego, co w tym kontekście pozwala na działania mające na celu utrzymanie pokoju, zapobieganie konfliktom i ogólnie umacnianie bezpieczeństwa międzynarodowego. WPZiB pozwala także na wspieranie trwałego rozwoju gospodarczego i społecznego oraz środowiskowego krajów rozwijających się, przyjmując za nadrzędny cel likwidację ubóstwaํ. Tak skonstruowana polityka zagraniczna daje predyspozycje do budowy

${ }^{1}$ Ponadto zgodnie z art. 21, celem WPZiB jest: zachęcanie wszystkich krajów do integracji w ramach gospodarki światowej, między innymi drogą stopniowego znoszenia ograniczeń w handlu międzynarodowym; przyczynianie się do opracowywania międzynarodowych środków służących ochronie i poprawie stanu środowiska oraz zrównoważonego zarządzania światowymi zasobami naturalnymi, w celu zapewnienia trwałego rozwoju; niesienie pomocy narodom, krajom i regionom dotkniętym klęskami żywiołowymi lub katastrofami spowodowanymi przez człowieka; wspieranie 
zaufania pomiędzy UE a jej partnerami z państw trzecich i otwiera drogę do podejmowania różnego typu działań z użyciem środków cywilnych i wojskowych.

Z kolei WPBiO, stanowiąca integralną część WPZiB i posiadająca zdolność operacyjną, umożliwia Unii Europejskiej odgrywanie wiodącej roli w operacjach pokojowych, zapobieganiu konfliktom oraz wzmacnianiu bezpieczeństwa międzynarodowego. Dodatkowo WPBiO jest pionierem kompleksowego podejścia (comprehensive approach) UE w zakresie zarządzania kryzysowego opartego na środkach cywilnych i wojskowych. Kompleksowe podejście do konfliktów i kryzysów zewnętrznych oznacza łączenie wszystkich możliwych instrumentów UE, od dyplomacji, poprzez bezpieczeństwo, obronę, finanse, aż po wsparcie i pomoc humanitarną. Kompleksowe podejście obejmuje wszystkie etapy cyklu konfliktu, począwszy od wczesnego ostrzegania i gotowości, poprzez zapobieganie konfliktom, stabilizację, odbudowę, budowanie pokoju i zrównoważonego rozwoju w perspektywie długoterminowej. W ten sposób Unia Europejska promuje główne cele polityczne oraz przyczynia się do poprawy jakości życia w państwach trzecich i zapobiega konfliktom (The EU's Comprehensive Approach to External Conflict and Crises, 2013, s. 2-3). Autorzy raportu The EU as a Security Power, podkreślają także, że kompleksowe podejście nie oznacza wyłącznie koordynacji narzędzi cywilnych i wojskowych do rozwiązywania kryzysów. Oznacza ono przede wszystkim współpracę publiczno-prywatną oraz łączenie instrumentów przestrzeni wolności, bezpieczeństwa i sprawiedliwości z wymiarem zewnętrznym Unii Europejskiej (Drent, Landman, Zandee, 2014, s. 15).

Cele i zadania WPBiO mogą świadczyć o zaawansowaniu procesu politycznego zmierzającego w kierunku uzasadnienia jej wojskowej i cywilnej obecności międzynarodowej. Ponadto Traktat z Lizbony nadał WPBiO możliwość tworzenia wspólnej obrony. Zatem zgodnie z art. 42 TUE, ust. 1 - celem WPBiO jest zapewnienie Unii Europejskiej zdolności operacyjnej opartej na środkach cywilnych i wojskowych. UE może z nich korzystać w międzynarodowych misjach utrzymania pokoju, zapobiegania konfliktom i wzmacniania bezpieczeństwa (Charalampous, 2010; Witney, 2013). Misje cywilne i operacje wojskowe mogą być także wykorzystywane do walki z terroryzmem i do wspierania państw trzecich w zwalczaniu tego zjawiska na ich terytorium (art. 43 TUE, ust. 1). Jest to pierwszy raz kiedy prawo pierwotne Unii Europejskiej wskazuje na wyraźny związek pomiędzy walką z terroryzmem a WPBiO (Hillion, 2014, s. 2). O polityce ekspedycyjnej w kontekście walki z terroryzmem była mowa już w Deklaracji z Sewilli z 2002 r. Podkreślone w niej zostało, że WPZiB wraz z WPBiO może odegrać ważną rolę w przezwyciężeniu terroryzmu i w umacnianiu pokoju i stabilności, dlatego ,[...] udzieli pomocy państwom trzecim w celu wzmocnienia ich możliwości skutecznego reagowania na międzynarodowe zagrożenie terroryzmem [...]", a także: ,[...] wzmocni dotychczas wykorzystywane instrumenty długoterminowego zapobiegania konfliktom [...]"' (Spotkanie Rady Europejskiej w Sewilli, 2002, s. 237-238). Zatem teoretycznie możliwości oddziaływania WPBiO na poprawę bezpieczeństwa zarówno zewnętrznego, jak i wewnętrznego Unii Europejskiej są duże.

Zatem należy uznać, że częścią polityki zewnętrznej Unii Europejskiej dedykowaną misjom cywilnym i operacjom wojskowym jest bez wattpienia polityka ekspedycyj-

systemu międzynarodowego opartego na silniejszej współpracy wielostronnej i na dobrych rządach na poziomie światowym. 
na jako wypadkowa dwóch wcześniejszych, bazowych polityk sektorowych WPZiB oraz WPBiO. Zdaniem Autorki wydaje się to być uzasadnione, ponieważ wspomniana grupa dwóch ewolucyjnych polityk nie wyczerpuje wystarczająco zagadnienia, gdyż żadna z tych polityk (ani WPZiB ani WPBiO, gdyż istnieją między nimi pewne współzależności) nie może być wyłącznie potraktowana jako wyspecjalizowana w zakresie wojskowych operacji i cywilnych misji międzynarodowych UE. Zarówno w praktyce wewnątrzunijnej, jak i w nauce można zauważyć tendencje do poszukiwania bardziej precyzyjnych ram politycznych dla tego typu aktywności Unii Europejskiej. Z tego względu wydzielenie z WPBiO wyspecjalizowanej polityki ekspedycyjnej, jako najbardziej adekwatnej dla podjętego przedmiotu analizy, ale jednocześnie, jako wręcz ekskluzywnej w tym obszarze aktywności Unii Europejskiej jest całkiem uprawnione ponieważ najważniejszym instrumentem WPBiO są misje cywilne i operacje wojskowe realizowane w wymiarze międzynarodowym, pozaunijnym, czyli ekspedycyjnym.

\section{Polityka ekspedycyjna jako wyraz realizacji unijnych celów w zakresie bezpieczeństwa}

Przez politykę ekspedycyjną należy rozumieć gotowość Unii Europejskiej do podjęcia działań zewnętrznych (out of area) wiążącą się z wysłaniem personelu cywilnego, wojskowego, bądź mieszanego, poza jej terytorium. W tym rozumieniu - działania zewnętrzne (ekspedycyjne) - przeznaczone są do realizowania określonych przez UE celów i zadań mających przyczynić się do poprawy bezpieczeństwa międzynarodowego oraz bezpieczeństwa samej UE. Zatem do celów podstawowych działań ekspedycyjnych (o proweniencji aksjologicznej) zaliczymy: przestrzeganie zasad demokracji, rządów prawa, ochronę praw człowieka i podstawowych wartości. Oznacza to, że Unia Europejska realizuje swoją politykę ekspedycyjną w oparciu o te cele, które jednocześnie są wartościami nadrzędnymi dla niej samej i jej państw członkowskich (art. 3 TUE, ust. 5: „W stosunkach zewnętrznych Unia umacnia i propaguje swoje wartości [...]”, a także art. 21, ust. 1: „Działania Unii na arenie międzynarodowej oparte są na zasadach, które leżą u podstaw jej utworzenia, rozwoju i rozszerzenia oraz które zamierza wspierać na świecie: demokracji, państwa prawnego, powszechności i niepodzielności praw człowieka i podstawowych wolności, poszanowania godności ludzkiej, zasad równości i solidarności oraz poszanowania zasad Karty Narodów Zjednoczonych oraz prawa międzynarodowego"). Dlatego wartości UE przekładają się na cele główne, które za pomocą działań ekspedycyjnych wdrażane są tam, gdzie występuje widoczny ich brak, lub gdzie wartości te są nagminnie naruszane.

Działania ekspedycyjne Unii Europejskiej są niejednokrotnie wynikiem ram strategicznych polityki UE wobec danego regionu (art. 22 TUE, ust. 1: „Na podstawie zasad i celów wymienionych w artykule 21 Rada Europejska określa strategiczne interesy i cele Unii. Decyzje Rady Europejskiej w sprawie strategicznych interesów i celów Unii dotyczą wspólnej polityki zagranicznej i bezpieczeństwa oraz innych dziedzin dotyczących działań zewnętrznych Unii. Decyzje te mogą dotyczyć stosunków Unii z określonym krajem lub regionem, lub określonego tematu. Określają one ich czas trwania oraz środki, które mają zostać udostępnione przez Unię i Państwa Człon- 
kowskie"). Stąd też instrumenty wchodzące w zakres realizowanych zadań mogą być zróżnicowane, od finansowych, po techniczne, doradcze czy humanitarne (Zob. Joint Communication to The European Parliament and the Council, The EU's Comprehensive Approach to External Conflict and Crises, Brussels, 11.12.2013 JOIN(2013) 30 final, The Stabilization and Association Process for countries of South-Eastern Europe, $\mathrm{i}$ inne).

Z kolei cele działań ekspedycyjnych, przyjęte na podstawie decyzji Rady UE są celami bardziej szczegółowymi, zoperacjonalizowanymi i dopasowanymi do przedmiotu danej misji cywilnej lub operacji wojskowej. Misje cywilne i operacje wojskowe Unii Europejskiej są głównymi narzędziami ekspedycyjnymi służącymi do realizacji celów UE w zakresie bezpieczeństwa (art. 42, ust. 1: „Wspólna polityka bezpieczeństwa i obrony stanowi integralną część wspólnej polityki zagranicznej i bezpieczeństwa. Zapewnia Unii zdolność operacyjną opartą na środkach cywilnych i wojskowych. Unia może z nich korzystać $\mathrm{w}$ przeprowadzanych poza Unią misjach utrzymania pokoju, zapobiegania konfliktom i wzmacniania międzynarodowego bezpieczeństwa, zgodnie z zasadami Karty Narodów Zjednoczonych. Zadania te są wykonywane w oparciu o zdolności, jakie zapewniają Państwa Członkowskie"). Misje cywilne, czy też operacje wojskowe - jako podmioty europeizacji ad extra - maja prowadzić do umacniania bezpieczeństwa w danym państwie czy regionie, jak również do zakorzeniania się dobrych praktyk, szczególnie w takich obszarach jak wymiar sprawiedliwości, wymiar policyjny i wojskowy. Działania wynikające z tego obszaru celów realizowane są w instytucjach sądowych, karnych, policyjnych, wojskowych, w punktach granicznych oraz portach lotniczych i morskich. Tego typu cele mają przyczyniać się do długotrwałej stabilizacji na danym terytorium, normalizacji sytuacji poprzez wyeliminowanie napięć pomiędzy władzą a obywatelami, strukturami policyjnymi a wojskowymi - w zależności od potrzeb państwa, oraz rozwijania poprawnych stosunków w przypadku zwaśnionych stron, a także budowanie zaufania, pomiędzy: władzą a obywatelami, strukturami bezpieczeństwa (siłami policyjnymi, służbami granicznymi, wymiarem sądowym) a obywatelami ${ }^{2}$. Unia Europejska ma tutaj szerokie pole do transferowania norm, standardów i najlepszych praktyk europejskich do instytucji państw trzecich.

Działania ekspedycyjne Unii Europejskiej w obszarze bezpieczeństwa nie są czymś nowym. Wyraźne symptomy wczesnej polityki ekspedycyjnej znajdowały się już w ramach Unii Zachodnioeuropejskiej (UZE) pod postacią zadań petersberskich ${ }^{3}$ (Dekla-

${ }^{2}$ Dla przykładu wszystkie decyzje Rady UE o ustanowieniu misji cywilnej odnoszą się do tego typu celów, np: Council Joint Action 2003/681/CFSP of 29 September 2003 on the European Union Police Mission in the Former Yugoslav Republic of Macedonia (EUPOL PROXIMA), OJ L 249, 1.10.2003, Council Joint Action 2005/889/CFSP of 12 December 2005 on establishing a European Union Border Assistance Mission for the Rafah Crossing Point (EU BAM Rafah), OJ L 327, 14.12.2005, Council Joint Action 2007/405/CFSP of 12 June 2007 on the European Union police mission undertaken in the framework of reform of the security sector (SSR) and its interface with the system of justice in the Democratic Republic of the Congo (EUPOL RD Congo), OJ L 151, 13.6.2007.

${ }^{3}$ Petersberg tasks, czyli: zadania humanitarne i ratunkowe (humantitarian and rescue tasks), zadania utrzymania pokoju (peacekeeping tasks) oraz zadania zbrojne służące zarządzaniu kryzysowemu, w tym przywracania pokoju (tasks of combat force in crisis management, including peacemaking). 
racja petersberska z 19 czerwca 1992 r., „Biuletyn Informacyjny”, 1993, s. 59-60). Dlatego zarówno one, jak i misje cywilne oraz operacje wojskowe po Traktacie z Lizbony - bez wyjątku - mają charakter operacji ekspedycyjnych, czyli typu out of area . Tezę tę potwierdzają także polityczne okoliczności rozwoju koncepcji autonomizacji zdolności wojskowych państw zachodnioeuropejskich (Żurawski vel Grajewski, 2012, s. 5; Meyers, 1993; Deighton, 1997; Davis Cross, 2011), od UZE po WPBiO (Zięba, 2001; Adamski, Johnson, Schweiss, 2006; Słomczyńska, 2007).

Dla zainicjowania polityki ekspedycyjnej Unii Europejskiej za istotne należy uznać wskazania Tony Blaira dotyczące wprowadzenia zmian w ramach Wspólnej Polityki Zagranicznej i Bezpieczeństwa. Oświadczył on wówczas, że nie można dłużej utrzymywać w obecnym kształcie WPZiB, a należy stworzyć europejską zdolność obronną, umożliwiającą państwom członkowskim UE wspólne prowadzenie operacji wojskowych, zwłaszcza misji utrzymywania pokoju (Zięba, 2005, s. 38; Winn, 2003; Peterson, Sjursen, 1998; Missiroli 2001) $)^{4}$.

O potrzebie rozwoju działań ekspedycyjnych mówił także Europejski Cel Operacyjny z 1999 r., który zakładał, że do 2003 r. UE powinna zbudować korpus ekspedycyjny w sile 50 000-60 000 żołnierzy, zdolnych do mobilizacji w ciągu 60 dni i prowadzenia działań nie krócej niż przez rok ${ }^{5}$. Dodatkowo decyzja o ustaleniu cywilnego mechanizmu zarządzania kryzysowego ${ }^{6}$ (w celu zwiększenia skuteczności środków i zasobów cywilnych - równolegle do wojskowych) przesądziła o podziale działań ekspedycyjnych UE na cywilne i wojskowe (Konkluzje prezydencji, „Monitor Integracji Europejskiej", s. 305; Lindstrom, 2005).

Faktycznie, przyjęty podział na misje cywilne i operacje wojskowe wziął się z praktyki, która z kolei uwarunkowana była przez udział konkretnego rodzaju personelu (cywilnego, w tym policyjnego, lub wojskowego) na potrzeby danej misji lub operacji. A zatem wszystkie działania ekspedycyjne Unii Europejskiej w zakresie zarządzania kryzysowego przybierają postać działań militarnych lub niemilitarnych, czyli cywilnych. Działania niemilitarne w zakresie zarządzania kryzysowego to przede wszystkim pomoc humanitarna, z kolei działania militarne to akcje humanitarne, ratunkowe, utrzymania pokoju, zbrojne - służące zarządzaniu kryzysowemu. Działania te wiążą się z realizacją celów Wspólnej Polityki Bezpieczeństwa i Obrony (Hoffman, 2010,

${ }^{4}$ Miało to miejsce podczas nieformalnego szczytu UE w październiku 1998 r. w Pörtschach.

${ }^{5}$ Europejski Cel Operacyjny omawiany był podczas szczytu Rady Europejskiej w Helsinkach, w dniach 10-11 grudnia $1999 \mathrm{r}$.

${ }^{6}$ Cywilne zarządzanie kryzysowe jest specyficzne dla Unii Europejskiej i nie ma realnego odpowiednika w leksykonach ONZ, OBWE czy też poza europejskich organizacjach regionalnych, zob. M. Kunh, 2009, The System of EU Crisis Management- From Bringing Peace to establish Democracy?, „Max Planck UNYB”, No. 13, s. 253. Pomimo, że jest ono powszechnie stosowane od 1995 r. w wielu dokumentach urzędowych Unii Europejskiej, jego znaczenie nie zostało jasno określone na szczeblu unijnym. Brak jasnej definicji cywilnego zarządzania kryzysowego jest w pewnym sensie związane z niejasnym zakresem cywilnych działań utrzymywania i budowania pokoju na poziomie międzynarodowym. Niejednoznaczność tego wyrażenia jest również związana z podziałem instytucjonalnym pomiędzy instrumentami cywilnymi stworzonymi w ramach dawnego I i II filara UE, i tym bardziej skomplikowanymi kwestiami dzielenia kompetencji w obszarze cywilnego zarządzania kryzysowego między Radę UE a Komisję Europejską, zob. A. Nowak, Civilian Crisis Management within ESDP, w: C. Gourlay, D. Helly, I. Ioannides, R. Khol, A. Nowak, P. Serrano, Civilian Crisis Management: The EU Way, „Chaillot Paper”, 2006, no. 90, s. 16. 
s. 99-100). Zatem rozszerzenie unijnego zarządzania kryzysowego o aspekt cywilny przesądziło o typie podejmowanych działań w ramach polityki ekspedycyjnej.

Zdarza się, że Unia Europejska łączy te dwa rodzaje działań (operacje zarządzania kryzysowego (crisis management operations) - komponent wojskowy oraz misje zarządzania kryzysowego (crisis management missions) - komponent cywilny w ramach WPBiO, choć jak podkreśla Maike Kuhn, jest to prawnie trudne do opanowania, ponieważ nie istnieje spójne i jednolite nazewnictwo w unijnych dokumentach odnośnie różnych działań, które UE może podjąć (Kuhn, 2009, s. 248). Niewątpliwie zarządzanie kryzysowe w Unii Europejskiej jest elementem polityki ekspedycyjnej i jej działań zewnętrznych. Również z łatwością może być przeznaczone do aktywności w wymiarze wewnętrznym, czyli przestrzeni wolności, bezpieczeństwa i sprawiedliwości. Ten wspólny element czy też czynnik polityki ekspedycyjnej UE wpisuje się w koncepcję integrowania tych dwóch wymiarów w zakresie walki ze wspomnianymi na samym początku artykułu zagrożeniami.

Należy zatem uznać, że polityka ekspedycyjna Unii Europejskiej jest rezultatem priorytetowych celów dwóch sektorowych polityk, tj. WPZiB i WPBiO, ale dedykowanym wyłącznie misjom międzynarodowym.

Celem unijnej polityki ekspedycyjnej jest realizacja interesów UE, promowanie i rozpowszechnianie wartości europejskich, rozwiązywanie kryzysów, eksport stabilizacji i europeizacji.

W sposób elementarny, jak wynika z powyższej analizy, politykę ekspedycyjną można podzielić na: cywilną i wojskową. Cywilna polityka ekspedycyjna obejmuje instrumenty prawne, społeczne, ekonomiczne, dyplomatyczne i kulturowe, oznacza to, że zakres zadań w ramach misji cywilnych sprowadza się do prowadzenia szkoleń, doradzania i monitorowania w strukturach obszaru bezpieczeństwa (policja, straż graniczna, wymiar sprawiedliwości i inne), a przede wszystkim promowania wartości europejskich i transferowania ich do państw trzecich (europeizacja ad extra). W ten sposób za pomocą polityki ekspedycyjnej UE ustanawiane są ramy współpracy na rzecz poprawy bezpieczeństwa w państwach trzecich, wzajemne podejmowanie działań w celu wzmocnienia tamtejszych struktur bezpieczeństwa, budowanie zaufania do władz lokalnych. Zakres wojskowej polityki ekspedycyjnej zawiera się w zadaniach petersberskich, co oznacza podjęcie działań mających na celu stabilizowanie sytuacji, nadzorowanie porozumień pokojowych czy ochronę ludności. Polityka ekspedycyjna, zarówno w wymiarze cywilnym, jak i wojskowym, w znaczący sposób może wpływać na bezpieczeństwo wewnętrzne UE, pod warunkiem, że jest efektywna. O efektywności polityki ekspedycyjnej świadczy komplementarność działań i długofalowe zaangażowanie.

Aktualnie największe działania ekspedycyjne Unii Europejskiej prowadzone są w Afryce: cztery operacje wojskowe (EUTM Mali, EUMAM RCA w Republice Centralnej Afryki, EUTM Somalia i EUNAVFOR Atalanta w Somalii), oraz pięć misji cywilnych (EUSEC RD Kongo, EUCAP Nestor w Somalii, EUCAP Sahel w Nigrze, EUCAP Sahel w Mali i EUBAM w Libii). Dodatkowo polityka ekspedycyjna w wymiarze cywilnym prowadzona jest w Azji (EUPOL Afganistan), Autonomii Palestyńskiej (EUPOL COPPS, EUBAM Rafah) i w Europie (EULEX w Kosowie, EUMM w Gruzji, EUAM na Ukrainie). Z kolei w wymiarze wojskowym polityka ekspedycyjna jest także obecna 
w Europie: (EUFOR Althea w Bośni i Hercegowinie), oraz na Morzu Śródziemnym (EUNAVFOR MED) $^{7}$. Zatem aktualna polityka ekspedycyjna Unii Europejskiej sprowadza się do jedenastu misji cywilnych i sześciu operacji wojskowych, z czego zdecydowana większość z nich ma miejsce na kontynencie afrykańskim.

\section{Przyszłość polityki ekspedycyjnej}

Przyszłość polityki ekspedycyjnej bez wątpienia wiąże się z dalszym rozwojem WPBiO, jej środków i zasobów. A tymczasem już konflikt w Libii w 2011 r. wskazywał na pewne ograniczenia zdolności Unii Europejskiej do radzenia sobie z sytuacją kryzysową - i to w jej bezpośrednim sąsiedztwie. Sytuacja ta wzbudziła wątpliwości co do skuteczności UE jako międzynarodowego menadżera kryzysowego i na nowo wznieciła dyskusję nad przyszłością WPBiO i jej kierunkiem. Ponieważ WPBiO została ustanowiona w celu zapewnienia UE zarówno cywilnych, jak i wojskowych zdolności reagowania na kryzysy międzynarodowe, to jednak brak zgody państw co do rodzaju działań w Libii spowodował znacznie opóźnioną reakcję (Matera, 2016, s. 1).

W 2013 r. zdeterminowani przywódcy państw członkowskich Unii Europejskiej przyznali, że: „Obronność jest ważna. Skuteczna wspólna polityka bezpieczeństwa i obrony (WPBiO) pomaga zwiększyć bezpieczeństwo europejskich obywateli oraz umacnia pokój i stabilność w naszym sąsiedztwie i na całym świecie. Ale warunki strategiczne i geopolityczne w Europie szybko się zmieniają. Budżety na obronność w Europie są ograniczone, co zmniejsza możliwości rozwijania, rozmieszczania i utrzymywania zdolności wojskowych. Rozdrobnienie europejskich rynków obronnych zagraża stabilności i konkurencyjności europejskiego sektora obrony i bezpieczeństwa” (Konkluzje z 20 grudnia 2013 r.). Oznaczało to, że Unia Europejska i jej państwa członkowskie powinny wziąć na siebie większą odpowiedzialność za reakcję na wyzwania, które wiążą się z podejmowaniem działań ekspedycyjnych. Konieczna okazuje się pogłębiona współpraca w zakresie obronności poprzez zwiększenie potencjału obronnego w celu zapobiegania kryzysom lub zarządzania nimi, o czym może świadczyć także zapis traktatu z Lizbony: „Państwa Członkowskie, w celu realizacji wspólnej polityki bezpieczeństwa i obrony, oddają do dyspozycji Unii swoje zdolności cywilne i wojskowe [...]”, oraz ,[...] zobowiązują się do stopniowej poprawy swoich zdolności wojskowych [...]" (art. 42 TUE, ust. 3). Póki co ten potencjał sprowadza się bardziej do misji cywilizacyjnej, prowadzonej przez Unię Europejską z użyciem miękkich środków, czyli tzw. soft power, w ramach której za pomocą działań ekspedycyjnych transferowane są wzorce, zasady i wartości oraz środki finansowe (techniczne). Natomiast faktyczne zwiększenie potencjału obronnego, poprzez sukcesywne zwiększanie wydatków na ten cel, umożliwi prowadzenie misji cywilnych i operacji wojskowych, nie tylko - jak uważa Jo Coelmont - w homeopatycznych dawkach, szczególnie misje cywilne i mieszane w zakresie reformy sektora bezpieczeństwa (Security Sector Reform - SSR), ale w pełni pozwoli na realizowanie skutecznych działań ekspedycyjnych cywilnych i wojskowych. A tymczasem według autora, operacje wojskowe

\footnotetext{
${ }^{7}$ Stan na maj 2016 r.
} 
wykazują brak trwałych rezultatów (brak jest tutaj kompleksowego podejścia, które tak chętnie i przy każdej okazji szefowie państw i rządów podkreślają). Natomiast państwa członkowskie nie są w stanie rozwiązać kwestii związanej z deficytem w zakresie zdolności wojskowych czy opracowania odpowiedniego mechanizmu podziału kosztów (Coelmont, 2015, s. 110).

Z tej przyczyny konkluzje Rady Europejskiej z grudnia 2013 r. były ważne dla WPBiO i jej działań ekspedycyjnych, przede wszystkim z uwagi na fakt, że obrona umieszczona została jako stały element obrad, uznano ją za priorytetową (chiefsache). Podejście top-down jest odtąd uzupełniane podejściem oddolnym (bottom-up) (Coelmont, 2015, s. 101). Priorytety, które wyznaczono wówczas to: zwiększanie skuteczności, widoczności i oddziaływania WPBiO oraz jej działań ekspedycyjnych.

W 2015 r. kiedy to państwa członkowskie Unii Europejskiej zmagały się z napływem uchodźców, Rada Europejska w konkluzjach z czerwca zaleciła budowanie bardziej skutecznej, widocznej i zorientowanej na wyniki WPBiO, dalsze rozwijanie zdolności, zarówno cywilnych, jak i wojskowych, oraz wzmacnianie europejskiego sektora obronnego. Zwróciła także uwagę na potrzebę: przydzielenia przez państwa członkowskie wystarczających środków na wydatki obronne oraz jak najefektywniejszego wykorzystania zasobów; zapewnienia $w$ ramach budżetu UE stosownych środków na działania przygotowawcze dotyczące badań związanych z WPBiO, co przygotowałoby grunt pod ewentualny przyszły program w dziedzinie badań $\mathrm{i}$ technologii obronnych; wspierania głębszej i bardziej systematycznej europejskiej współpracy w dziedzinie obronności - w tym z wykorzystaniem środków unijnych - w celu zapewnienia kluczowych zdolności, jak również uruchomienia instrumentów UE wspomagających przeciwstawianie się zagrożeniom hybrydowym (Posiedzenie Rady Europejskiej, 2015, s. 6).

Dynamiki w polityce ekspedycyjnej nadaje wspólny raport Wysokiego Przedstawiciela Unii ds. Zagranicznych i Polityki Bezpieczeństwa i Komisji Europejskiej dotyczący wpływu i zmian w globalnym środowisku oraz wynikających z tego wyzwań i możliwości dla Unii Europejskiej z maja 2015 r. (The European Union in a changing global environment. A more connected, contested and complex world, 2015). Raport ten wydaje się być dość istotnym dokumentem z uwagi na jego nowe, multidyscyplinarne podejście do kwestii bezpieczeństwa, WPBiO i polityki ekspedycyjnej. Analiza raportu pozwala na stwierdzenie, że jego główne założenia symbolizują nowe podejście w polityce ekspedycyjnej, które związane jest z kryzysem migracyjnym z 2015 r. i jego skutkami, np. rozwojem radykalnych postaw wśród nowych przybyszy wobec państw Unii Europejskiej, zamieszek czy nawet aktów terroryzmu.

W raporcie wskazuje się na konieczność łączenia i synergicznego współdziałania wymiaru wewnętrznego bezpieczeństwa $\mathrm{z}$ wymiarem zewnętrznym - jako jednej całości (dla przypomnienia podobny zapis znalazł się w konkluzjach Rady Europejskiej z 2013 r., oraz w mapie drogowej z roku 2011, gdzie zostały zidentyfikowane obszary praktycznej współpracy pomiędzy podmiotami przestrzeni wolności, bezpieczeństwa i sprawiedliwości a WPBiO: m.in. wymiana informacji wywiadowczych pomiędzy Frontexem a Centrum Analiz Wywiadowczych (INTCEN), dzielenie się informacjami pomiędzy Europolem a Europejską Służbą Działań Zewnętrznych, czy zaangażowanie Eurojustu w misje WPBiO, zob. Ties between CSDP and FSJ, 2011, s. 7-16), 
bez której dziś, w dobie zagrożeń terroryzmem czy napływu migrantów, Unia Europejska nie będzie w stanie zbudować skutecznej obrony przed tymi, jak i innymi jeszcze zagrożeniami. W raporcie przede wszystkim zostało podkreślone, że WPBiO jest pionierem kompleksowego podejścia (comprehensive approach) do kwestii związanych z zewnętrznymi kryzysami i konfliktami, i że to kompleksowe podejście jest jeszcze bardziej istotne teraz niż dziesięć lat temu. W dobie rozprzestrzeniania się zagrożeń i ich eskalacji, polityka Unii Europejskiej powinna być bardziej proaktywna niż reaktywna i łączyć pewne elementy, takie jak wczesne ostrzeganie, zapobieganie konfliktom, zarządzanie kryzysami i budowanie pokoju. Ale łączenie wymienionych elementów będzie możliwe dzięki współpracy instrumentów WPBiO, czyli między innymi misji ekspedycyjnych z innymi instrumentami, które ma do dyspozycji Unia Europejska w wymiarze wewnętrznego bezpieczeństwa. Zatem, aby budować efektywną politykę bezpieczeństwa Unii Europejskiej konieczna jest koordynacja działań wewnętrznych z zewnętrznymi, szczególnie jeśli chodzi o walkę z terroryzmem i zagrożenia hybrydowe. Tylko kompleksowe podejście, zapoczątkowane $\mathrm{w}$ ramach WPBiO, ma szansę na powodzenie i - co warto podkreślić - jest konieczne nie tylko do walki z zewnętrznymi konfliktami, ale także dla każdego aspektu międzynarodowej obecności Unii Europejskiej, nie tylko misji cywilnych czy operacji wojskowych.

Jak już zostało wspomniane, Unia Europejska może polegać na szerokim zestawie narzędzi do podejmowania wyzwań, które w zdegradowanym środowisku bezpieczeństwa mają zasadnicze znaczenie, wystarczy jedynie rozwijać synergię pomiędzy polityką bezpieczeństwa wewnętrznego i zewnętrznego, pomiędzy polityką ekspedycyjna, czyli misjami cywilnymi i operacjami wojskowymi a unijnymi agencjami, kojarzonymi do tej pory z bezpieczeństwem wewnętrznym UE. Zatem kompleksowe podejście (comprehensive approach) powinno być przeniesione na obszar wszystkich dziedzin działań zewnętrznych Unii Europejskiej, jako wspólne podejście (joined-up approach). Ponieważ kompleksowe podejście nie odnosi się tylko do połączonego wdrażania instrumentów (joined-up deployment) i zasobów, ale także do dzielenia odpowiedzialności (shared responsibility), wspólnej, tj. pomiędzy podmiotami na szczeblu Unii Europejskiej i państwami członkowskimi. Dlatego sukcesem działania $\mathrm{w}$ dobie nowych wyzwań, zapoczątkowanych przez falę migracji jest nie tylko kompleksowe podejście, ograniczane do WPBiO i jej działań ekspedycyjnych, ale przede wszystkim wspólne podejście (joined-up approach), obejmujące zarówno instrumenty WPBiO, jak i pozostały szeroki wachlarz instrumentów, jakimi dysponuje Unia Europejska włącznie z jej agencjami ds. bezpieczeństwa wewnętrznego, oraz z dzieleniem odpowiedzialności w ramach bezpieczeństwa wewnętrznego i zewnętrznego (The European Union in a changing global environment. A more connected, contested and complex world, 2015). Zatem nowe podejście Unii Europejskiej do kwestii bezpieczeństwa można określić jako wspólne i kompleksowe (joined-up comprehensive approach).

Konkludując, raport z 2015 r. jest przełomowy w kwestii podejścia Unii Europejskiej do bezpieczeństwa, jak również prowadzonej przez nią polityki ekspedycyjnej. Łączenie polityki ekspedycyjnej z wymiarem wewnętrznym, a szczególnie z agencjami UE właściwymi dla bezpieczeństwa wewnętrznego UE i przejście od kompleksowego podejścia (comprehensive approach) do wspólnego podejścia (joined-up approach), 
stanowi w pewnym sensie novum dla polityki ekspedycyjnej i innych sektorowych polityk Unii Europejskiej.

Warto zauważyć, że zmiany w podejściu do kwestii bezpieczeństwa można odnotować już w praktyce unijnej przy niektórych misjach cywilnych i wojskowych, tj. łączenie kompleksowego podejścia (comprehensive approach) i wspólnego podejścia (joined-up approach). Dla przykładu: agencje UE, takie jak Europol, Frontex, Eurojust - zaangażowane są w misje cywilne (policyjne, rządów prawa, czy operacja morska Sofia ${ }^{8}$ ), nowością jest zaangażowanie się Europolu w operację wojskową ${ }^{9}$ Dla polityki ekspedycyjnej ma to ogromny wpływ, dynamizujący, ponieważ, po pierwsze WPBiO i działania ekspedycyjne stały się filarami polityki bezpieczeństwa wewnętrznego, a po drugie polityka ekspedycyjna Unii Europejskiej staje się bardziej wspólna, w ramach wspólnego podejścia (joined-up approach), dzięki włączaniu się w misje cywilne i operacje wojskowe wspomnianych agencji Unii Europejskiej.

$Z$ powodzeniem WPBiO oraz uzależniona od niej polityka ekspedycyjna mogą dalej ewoluować, umocnieniu mogą ulec ramy instytucjonalne, zaś współpraca między państwami członkowskimi i strukturami Unii Europejskiej może być wzmacniana. Mimo wszystko państwa członkowskie UE powinny lepiej wykorzystywać kompleksowe podejście, które odnosi się przecież do strategicznej spójności w stosowaniu różnych instrumentów UE poprzez: osiągnięcie lepszej integracji struktur cywilnych i wojskowych, opracowanie strategii regionalnych w celu bardziej efektywnej współpracy, zapewnienie lepszej koordynacji pomiędzy różnego rodzaju europejskimi instrumentami i podmiotami w ramach WPBiO. Z kolei państwa członkowskie powinny zobowiązać się do rozwoju zdolności cywilnych i wojskowych, aby cele i możliwości WPZiB i WPBiO były spójne poprzez: lepsze łączenie zasobów i współpracy strukturalnej, ustanowienie stałej siedziby planowania zdolności (zamiast ad hoc), wdrożenie istniejących projektów i rozwój nowych, większych projektów, wytyczenie celu dla zdolności wojskowych w nowym celu operacyjnym, zwiększenie środków dla Europejskiej Agencji Obrony, zgoda na wspólne finansowanie grup bojowych ${ }^{10} \mathrm{UE}$ i rozmieszczenia ich jako sił szyb-

${ }^{8}$ Celem tej operacji wojskowej jest zniszczenie sieci przemytników ludzi i handlarzy ludźmi działających na Morzu Śródziemnym oraz uniknięcie kolejnych tragedii na morzu. Jest to część szerszego, kompleksowego podejścia Unii Europejskiej do kwestii migracji, zakładającego, że podejmowane działania powinny w tym samym stopniu koncentrować się na skutkach migracji, jak i na jej przyczynach, czyli konfliktach, ubóstwie, zmianie klimatu i prześladowaniach.

${ }^{9}$ Przykładem jest zaangażowanie Europolu w misje rządów prawa (EULEX), podjętą w 2008 r. w Kosowie, gdzie Europol dostarcza personelowi misji informacji kryminalnych przechowywanych w swojej bazie danych. $\mathrm{Z}$ kolei Frontex zaangażowany jest w misję wsparcia granicznego $(E U$ Border Assistance Mission), podjętą w 2013 r. w Libii. Frontex wspiera misję poprzez powadzenie rekrutacji personelu oraz poprzez szkolenie libijskich służb granicznych. Natomiast na podstawie dokumentu (Memorandum of Understanding) z 22 grudnia 2015 r. Zarówno Europol, jak i Eurojust i Frontex zaangażowały się w wojskową operację na Morzu Śródziemnym (EUNAVFOR MED). Europol asystuje w identyfikacji grup kryminalnych zaangażowanych w przemyt ludzi, zob. F. Trauner, New Kids on the CSDP Block: The JHA Agencies, „Brief ISSUE”, 2016, no. 7, s. 2-3.

${ }^{10}$ Koncepcja grup bojowych UE zapewnia WPBiO instrument wczesnego i szybkiego wojskowego reagowania kryzysowego. Grupa bojowa to zespół jednostek - składający się z około 1500 (zwykle pochodzących z wielu państw) żołnierzy (minimum dla zapewnienia skuteczności operacji) - zdolnych do samodzielnych działań lub kierowania początkową fazą większych operacji. Grupy bojowe UE osiagnęły gotowość do działania już w styczniu 2005 r. Za: J. Legrand, Wspólna Poli- 
kiego reagowania (Rapid Reaction Forces). Konieczne jest, aby dążyć do stymulowania synergii cywilnej i wojskowej - szczególnie w zakresie badań i technologii - celem efektywnego wykorzystania zasobów. Nie bez znaczenia jest zapewnienie praw personelowi wojskowemu (oddelegowanemu do pracy w działaniach ekspedycyjnych) i prowadzenie pogłębionej współpracy i harmonizacji w tej dziedzinie (opracowanie wspólnych standardów). Kwestią dość często poruszaną jest określenie konkretnych sposobów na zwiększenie współpracy z NATO na rzecz silniejszego partnerstwa, bez zbędnego dublowania kompetencji w zakresie polityki ekspedycyjnej. Zatem jak można skonstatować - tylko z mocnymi decyzjami i jasnym poczuciem obranego kierunku Unia Europejska będzie w stanie wzmocnić swoją globalną pozycję i zapewnić bezpieczeństwo w wymiarze wewnętrznym i zewnętrznym (A Fresh Impetus, 2014, s. 1-2).

\section{Podsumowanie}

Sumując, należy zauważyć, że niezwykle istotnym trendem w ostatnich latach stało się przywiązywanie wagi do zwiększenia synergii między WPBiO a podmiotami działającymi w przestrzeni wolności, bezpieczeństwa i sprawiedliwości. Ma to związek z próbami wykorzystywania przez Unię Europejską kompleksowego podejścia (comprehensive approach), które odnosi się do strategicznej spójności w stosowaniu różnych instrumentów poprzez chociażby osiągnięcie lepszej integracji struktur cywilnych i wojskowych, rozwijaniu strategii regionalnych, a to wszystko w celu bardziej efektywnej współpracy oraz zapewnienia lepszej koordynacji pomiędzy różnego rodzaju europejskimi instrumentami i podmiotami w ramach WPBiO (A Fresh Impetus, 2014, s. 1-2). To podejście sprawia, że polityka ekspedycyjna w ramach WPBiO mogłaby na większą skalę i sukcesywnie poszerzać zasięg i zajmować się kwestiami horyzontalnymi, takimi jak nielegalna migracja, przestępczość zorganizowana oraz terroryzm, przy wsparciu m.in. takich agencji UE jak Europol, Eurojust czy Frontex. Na dzień dzisiejszy taka współpraca istnieje, lecz nie jest ona zbyt efektywna. Czynnikiem osłabiającym politykę ekspedycyjną w ramach WPBiO jest fakt, iż większość zalecanych działań ma charakter deklaratywny, który nie przekłada się na wymiar praktyczny, lub jeśli się przekłada to w niewielkiej dawce. Takie jedynie deklaratywne podejście osłabia WPBiO podważając jej nadrzędną rolę w zakresie bezpieczeństwa zewnętrznego. Strukturalnie WPBiO robi wrażenie, a jej misje cywilne i operacje wojskowe rozlokowane na trzech kontynentach dają poczucie silnej polityki ekspedycyjnej UE. Ta polityka powinna być jednak wzmocniona poprzez stanowcze decyzje, zaś WPBiO poprzez polityczną wolę rozwoju.

Niewątpliwie zarówno WPZiB jak i WPBiO odgrywają znaczącą rolę w wytyczaniu i realizowaniu zadań w obszarze bezpieczeństwa, a coraz mocniejszy nacisk na kompleksowe podejście sprawia, że w przyszłości polityka ekspedycyjna może stać się jednym z ważniejszych filarów wpływających na poprawę bezpieczeństwa wewnętrznego Unii Europejskiej.

tyka Bezpieczeństwa i Obrony, http://www.europarl.europa.eu/atyourservice/pl/displayFtu.html?ftuId=FTU_6.1.2.html, 12.07.2016. 


\section{Bibliografia}

A Fresh Impetus to the Common Security and Defence Policy. Recommendations to the European Union heads of state and government,http://europeanmovement.eu/wp-content/uploads/2014/11/MC-2013-005-EU-DEFENCE.pdf, 8.06.2016.

Adamski J., Johnson M. T., Schweiss Ch. M. (2006), Old Europe, New Security. Evolution for a Complex World, New York.

Charalampous M. (2010), From a European to a Common Security and Defence Policy, „IES Working Paper", no. 5.

Coelmont J. (2015), CSDP: There is something where that was there before, w: The Common Security and Defence Policy: National Perspectives, red. D. Fiott, „Egmont Paper”, no. 79.

Council Joint Action 2008/133/CFSP of 18 February 2008 amending and extending the mandate of the European Union Special Representative for the Middle East peace process, OJ L 43, 19.12.2008.

Council of European Union, Draft European Union Programme for the Prevention of Violent Conflict, 9537/1/01, REV 1.

Davis Cross M. K. (2011), Security Integration in Europe: How Knowledge-based Networks Are Transforming the European Union, Michigan.

Deighton A. (red.), (1997), Western European Union 1954-1997: Defence, Security, Oxford.

Deklaracja petersberska z 19 czerwca 1992 r. (1993), „Biuletyn Informacyjny”, z. 5 (21), Kancelaria Sejmu, Biuro Stosunków Międzyparlamentarnych.

Drent M., Landman L., Znadee D. (2014), The EU as a Security Power, Clingendael Report.

European Commission, The Stabilization and Association Process for countries of South-Eastern Europe, Brussels, 26 May 1999, COM (99) 235.

Hillion Ch., Fighting Terrorism Through the EU Common Foreign and Security Policy, http://papers. ssrn.com/sol3/papers.cfm?abstract_id=2383243, 12.07.2016.

Hoffman T. (2010), System reagowania kryzysowego w regulacjach Unii Europejskiej, „Zeszyty Naukowe WSOWL", nr 3 (157).

Hybrydowe zagrożenia, http://ec.europa.eu/polska/news/160406_hybrid_pl.htm, 12.07.2016.

Joint Communication to The European Parliament and the Council, The EU's Comprehensive Approach to External Conflict and Crises, Brussels, 11.12.2013 JOIN(2013) 30 final.

Joint Communication to The European Parliament and the Council, The EU's Comprehensive Approach to External Conflict and Crises, Brussels, 11.12.2013 JOIN(2013) 30 final, http://www. eeas.europa.eu/statements/docs/2013/131211_03_en.pdf, 4.04.2016.

Kuhn M. (2009), The System of EU Crisis Management- From Bringing Peace to establish Democracy?, „Max Planck UNYB”, no. 13.

Legrand J., Wspólna Polityka Bezpieczeństwa i Obrony, http://www.europarl.europa.eu/atyourservice/pl/displayFtu.html?ftuId=FTU_6.1.2.html, 12.07.2016.

Lindstrom G. (2005), The Headline Goal, Institute for Security Studies, no. 82.

Matera M., The Common Security and Defence Policy (CSDP) Post Libya: A Watershed Moment for the Future of the CSDP, http://www.uaces.org/events/conferences/bilbao/papers/abstract. php?paper_id=186\#.V3-0RvmLTrd, 8.06.2016.

Missiroli A. (2001), Coherence for European security policy: debates, cases and assessments. „Occasional Paper", no. 27, Paris, WEU Institute for Security Studies.

Meyers J. A. (1993), The Western European Union: pillar of NATO or defence of the EC?, University of London, Centre for Defence Studies.

Nowak A. (2006), Civilian Crisis Management within ESDP, w: C. Gourlay, D. Helly, I. Ioannides, R. Khol, A. Nowak, P. Serrano, Civilian Crisis Management: The EU Way, „Chaillot Paper”, no. 90. 
Overview of the current EU mission and operations, May 2016, http://www.eeas.europa.eu/csdp/ missions-and-operations/index_en.htm, 16.05.2016.

Peterson J., Sjursen H. (red.), (1998), A Common Foreign Policy for Europe? Competing visions of the CFSP, Routledge, London-New York.

Posiedzenie Rady Europejskiej (25 i 26 czerwca 2015 r.), konkluzje, EUCO 22/15.

Rada Europejska (19-20 grudnia 2013), konkluzje, EUCO 217/13.

Słomczyńska I. (2007), Europejska Polityka Bezpieczeństwa i Obrony. Uwarunkowania - struktury - funkcjonowanie, Lublin.

Smith M. E. (2004), Europe's Foreign and Security Policy, Cambridge.

Sobczyk K. (2015), Konflikt na Ukrainie - porażka czy szansa dla WPBiO UE?, „Bezpieczeństwo Narodowe", $\mathrm{nr} 1$.

Soloch P. (1997), Koncepcje europejskiej obrony, w: Bezpieczeństwo europejskie; koncepcje, instytucje, implikacje dla Polski, red. J. Czaputowicz, Warszawa.

Spotkanie Rady Europejskiej w Sewilli, 21-22 czerwca 2002 r., Spotkania Rady Europejskiej 1993-2002, „Monitor Integracji Europejskiej”.

Szczyt Rady Europejskiej w Helsinkach, 10-11 grudnia 1999 r. Konkluzje prezydencji, „Monitor Integracji Europejskiej”.

The European Union in a changing global environment. A more connected, contested and complex world, http://eeas.europa.eu/docs/strategic_review/eu-strategic-review_strategic_review_ en.pdf, 30.03.2016.

Ties between CSDP and FSJ: Road Map Implementation, Fourth Annual Progress Report, Brussels, 19 November 2015, 14322/15.

Trauner F. (2016), New Kids on the CSDP Block: The JHA Agencies, „Brief ISSUE”, no. 7.

Wersja skonsolidowana Traktatu o Unii Europejskiej, Dz. U. C 115, 9.5.2008.

Winn N. (2003), CFSP, CESDP, and the Eastern Enlargement of the European Union: Evolution in the Brussels Institutions?, „World Affairs”, vol. 7, no. 1.

Witney N. (2013), Where Does CSDP Fit in EU Foreign Policy?, „Notre Europe Policy Paper”, no. 64.

Youngs R. (2004), Normative Dynamics and Strategic Interests in the EU's External Identity, „Journal of Common Market Studies", vol. 42, no. 2.

Zięba R. (2001), Europejska Tożsamość Bezpieczeństwa i Obrony, Warszawa.

Zięba R. (2005), Wspólna Polityka Bezpieczeństwa i Obrony, Warszawa.

Zwanenburg M. (2005), Accountability of Peace Support Operations, „International Humanitarian Law Series", Martinus Nijhoff Publishers, The Netherlands.

Żurawski vel Grajewski P. (2012), Wplyw kryzysu w strefie euro na Wspólnq Polityke Zagraniczna i Bezpieczeństwa oraz Wspólnq Politykę Bezpieczeństwa i Obrony Unii Europejskiej. Ocena przydatności instrumentarium unijnego z punktu widzenia jego użyteczności jako narzędzia polskiej polityki zagranicznej, „Analizy Natolińskie”, nr 5 (57).

\section{Streszczenie}

Import zjawisk stanowiących zagrożenie dla bezpieczeństwa wewnętrznego Unii Europejskiej w dość bolesny sposób odbija się na państwach członkowskich, powodując chaos na szczeblach decyzyjnych, co w konsekwencji osłabia całą UE. To z kolei wpływa na postrzeganie Unii Europejskiej jako słabej, nieradzącej sobie z problemami. Dlatego Autorka poddała analizie rolę polityki ekspedycyjnej w ramach WPBiO dla bezpieczeństwa wewnętrznego i zewnętrznego UE.

Słowa kluczowe: bezpieczeństwo, WPBiO, WPZiP, polityka ekspedycyjna 


\title{
The future of European Union expeditionary policy under the Common Security and Defence Policy
}

\begin{abstract}
Summary
Import dangerous phenomena to the European Union causes a main threat to its internal security and in a very painful way affects for the Member States, causing chaos on the decisionmaking levels, which in turn weakens the whole of the EU. This in turn affects the perception of the European Union as weak, not deal with problems. Therefore, the author analyzed the role of policy expeditionary CSDP to internal and external security EU.
\end{abstract}

Key words: security, CSDP, CFSP, policy expeditionary 
